\title{
Sustainable Design in the Furniture Industry
}

DOI 10.18267/pr.2021.krn.4816.20

\author{
Renáta Ševčíková ${ }^{1}$ - L'ubica Knošková ${ }^{2}$ \\ ORCID iD: 0000-0002-0575-721911,0000-0002-7302-4420² \\ renata.sevcikova@euba.sk, lubica.knoskova@euba.sk \\ 1,2 University of Economics in Bratislava, Faculty of Commerce, Department of \\ Commodity Science and Product Quality \\ Bratislava, Slovakia
}

\begin{abstract}
Designers have considerable responsibility for shaping the current state of products and services. To reduce the negative environmental impact of the furniture industry, designers need to change the way they design, while consumers need to change their attitudes towards sustainable furniture. However, companies that offer sustainable furniture face a frustrating paradox. Most consumers report positive attitudes towards environmentally friendly products and services, but this attitude does not seem to be reflected on their shopping behaviour. The aim of the paper is to provide an insight into the possibilities of applying sustainability in the furniture industry and to support discussion about the connection between the concept of sustainable development and consumption in the furniture industry. The methodology of the paper consists of a profound literature review and analysis in the area of sustainable development, sustainable consumption, sustainable design and their application in the furniture industry. Synthesis of literature review resulted in several recommendations how to align consumer shopping behaviour with the concept of sustainable furniture in line with new trends in the furniture industry.
\end{abstract}

Keywords: sustainability, furniture design, circular design

JEL Classification codes: M31, Q56

\section{INTRODUCTION}

The sustainable design, as a part of comprehensive sustainable development, has received considerable attention in recent years due to several global crises, such as climate change, famine, disease and poverty. In the last decade, there have been many academic and nonacademic discussions about introducing a different design task. Concepts such as "eco-design", "green design", "environmental design" and "sustainable design" have emerged, looking for alternative ways to cause less damage to the environment.

Designers, whose work forms the interface between humans and science, technology, and business, have the obligation and opportunity to shape the drivers of the new "green" economy, and to be on the front lines of that effort. Nowadays design is faced with the challenge to contribute to the transition towards a sustainable society (Spangenberg et al, 2010).

\section{LITERATURE REVIEW}

For a better understanding of the concepts, some contextual and background information is presented below. 


\subsection{Evolution of environmental design philosophies}

Designers have an excellent opportunity to influence what impact products will have on the environment and society throughout their life cycle. It is in the product design phase that decisions are made about costs, appearance, choice of materials, performance and quality features such as repairability, ease of maintenance and durability.

Today, greening is a "trend" and an opportunity for companies for many reasons, such as achieving competitiveness, legal regulations or corporate social and environmental responsibility. Many companies are thus trying to include environmental sustainability factors in their product concept (Ko, 2020).

Papanek's book Design for the Real World: Human Ecology and Social Change, which appeared for the first time in 1971 is considered a key work that brings an environmental perspective to the world of designers. Papanek provided a thorough critique of the design profession, a sophisticated response aimed not only at improving the outputs of design activities, but also at supporting the transformation of the design profession.

Subsequently, the first approach to the integration of environmental aspects into design emerges - green design, which, however, focuses only on individual problems such as reducing the amount of material used, replacing original materials with recycled materials or reducing energy consumption.

Ecodesign adds another dimension to traditional design - design is assessed in terms of the product's impact on the environment throughout its life cycle (Dostatni, 2015). It focuses on improving the environmental performance of a product during its life cycle, without prejudice to other basic criteria such as performance, functionality, aesthetics and quality. The main environmental impacts that are taken into account in ecodesign, include the minimization of material and energy consumption, the selection of less unfavorable materials and the promotion of long-life products (Albæk et al, 2020). Ecodesign focuses exclusively on environmental characteristics and does not consider the social dimensions of sustainability, which cover issues related to the distribution of resources and the related social impacts of a product (Ceschin and Gaziulusoy, 2016).

Sustainable design then took a step forward by considering social issues, including usability, socially responsible use and sourcing (Moreno et al., 2016). However, this approach still follows a linear model of the economy.

Circular design aims to reduce the loss of value contained in products and materials by keeping them circulating in closed loops. These cycles, such as reuse, repair, refurbishment or recycling, extend the product life cycle and increase resource productivity. Both circular design and sustainable design focus on environmental, economic and social aspects. However, they differ considerably in how they achieve their goals. Sustainable design gives the product a central role in protecting the value of the product and its environmental impact. On the other hand, circular design begins by optimizing the economic potential of resources through new business models. At the same time, emphasis is placed on resource renewal and quality of life (Medkova and Fifield, 2016). Bakker notes that the circular approach contrasts with the traditional linear business model of production of take-make-use-dispose and an industrial system largely reliant on fossil fuels, because the aim of the business shifts from generating profits from selling artifacts, to generating profits from the flow of materials and products over time (Bakker et al., 2014). 


\subsection{Sustainable Consumption}

The consumption in the recent decades has significantly increased, today's consumers tend to over-consume and buy new products, although this does not need to be necessarily. This may be due to the new trends, the fact that repair costs are too expensive, or that people want to own new products and features.

Mont and Plepys (2008) describe that there is a lack of knowledge on how to move from materialistic thinking to the more non-materialistic to reduce consumption. Increasing consumption of consumers in industrialized countries makes it difficult to work towards a more sustainable future.

Cooper (2005) explains that consumers play a key role in sustainable development. Sustainable consumption has been defined as "patterns of consumption through which the purchase and use of goods and services meet people's needs while minimising any environmental degradation" (Cooper, 2000). For a change in consumption, consumers' behaviour towards their products needs to change. Reducing our throwaway culture will assist in the progression towards an environmentally friendly attitude to consumption and will help in the overall drive to sustainable development (McCollough et al, 2018).

Cooper's (2005) model of sustainable consumption (Figure 1) indicates the potential product longevity has on slowing consumption rates. He suggests that the rate of consumption is reduced when products are easy to maintain.

\section{Fig. 1 - Model of sustainable consumption}

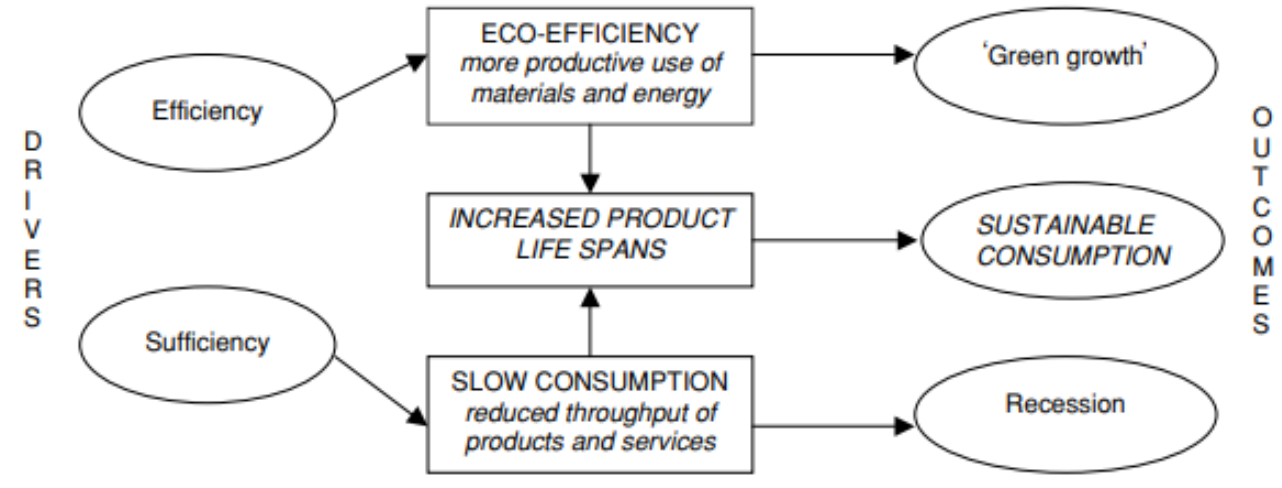

Source: Cooper, 2005, p. 55

Around $80 \%$ of a product's environmental impact can be eliminated through better design. Designers are under increased pressure to produce products with a sustainable outcome. They need to respond to current consumption rates, designing products that last longer and satisfy the needs of the user (Cooper, 2000).

\section{METHODOLOGY}

The methodology of the paper consists of a profound literature review and analysis in the area of sustainable development, sustainable consumption, sustainable design and their application in the furniture industry. We studied and analyzed a number of sources from Web of knowledge, Web of science and Scopus and from case studies that research the implementation of sustainable design in the furniture industry and evaluate the results. We identified sustainability, design and furniture as the three main subjects to be addressed and 
their interconnections should be studied. We focused on the development of sustainable design, especially its tools and strategies, to understand how and where improvements can be made in the design process that combine the criteria of sustainability with the needs of the furniture sector.

The aim of the paper is to provide an insight into the possibilities of applying sustainability in the furniture industry and to support discussion about the connection between the concept of sustainable development and consumption in the furniture industry. Deeper knowledge of the environmental impacts of materials and processes used in the furniture industry, as well as awareness of customer criteria for sustainable furniture, allow companies to accept the concept of sustainability. By reviewing of current trends in the furniture industry and consumer expectations, we provide the suggest and the opportunity to increase the competitiveness of products furniture industry by applying the principles of sustainable design.

We asked following research questions:

1. Is sustainable design an opportunity for the development of the furniture industry and the reduction of environmental impact?

2. Is sustainable design in the furniture industry in line with current trends and consumer expectations?

\section{RESULTS AND DISCUSSION}

In this part of the paper, we synthesize, analyse and compare the case studies, best practices of furniture companies that have introduced elements of sustainable design. We also analyse current trends and shopping behaviour and consumer expectations.

\subsection{Sustainable design - an opportunity for the company}

The wood and especially the furniture industry is known for being among the biggest resource consumers and is a big generator of residues. The analysis of the key environmental issues in the furniture sector reveals that the most important environmental impacts of the furniture sector relate to the consumption of raw materials such as wood and energy, the use of chemical substances containing volatile organic compounds and/or formaldehyde, and waste production (Olkowicz and Grzegorzewska, 2014).

Designers have great opportunity to influence the impact that products have on the environmental and society. The relevance of the early stages of product development is supported by the European Commission (2018), which stated that more than $80 \%$ of the environmental impact of a product is determined at the design stage.

The results of a qualitative study on furniture design teams in Malaysia led to the conclusion that the main challenges for sustainable design in furniture industry contain: (1) limited knowledge of sustainable design principles among design teams, (2) lack of awareness about sustainability among furniture buyers, (3) lack of a clear vision for future progress of furniture industry in sustainability, (4) lack of strategic thinking, (5) and weakness in copyright law (Valipoor \& Ujang 2011).

Within the Nordic countries of Europe, the furniture market is known for high quality and design furniture. A study on sustainability and the main factors impacting greenhouse gas (GHG) emissions from wood-based furniture based in Finland was carried out. The study showed that the GHG emissions mainly came from four different factors: materials, packaging, logistics and the process of manufacturing. Materials and production stood for the main part of the GHG emissions, while transportation and packaging resulted in less impact than the 
others. One suggestion was that industries could implement a lifecycle thinking; a systematic framework where the environmental thinking is covered of a product's entire lifecycle (Linkosalmi et al., 2016)

A case study made in Brazil investigated wood-based furniture using the Life Cycle Assessment model to analyse sustainable strategies and estimate the environmental performance. The result showed that the product distribution and supply of raw material phase had the most significant environmental impact with 68 percent, and the manufacturing process was only responsible for 7 percent of the overall wardrobe life cycle (Iritani et al., 2015).

Lewandowska et al (2017) concluded that the analysis of the design solutions from the point of view of several criteria (costs, environmental impact, social aspects) and several life cycle stages shows the complexity of the decision-making process and difficulties in selecting a clearly favourable solution. Environmentally preferred materials may be difficult for users to accept due to their costs. On the other hand, materials that have a high environmental impact on the production stage may show a great potential for final disposal (reuse, recycling), which affects their final assessment in the context of the whole life cycle.

The environmental design parameters, which were developed specifically for the furniture industry are presented in Table 1 . These environmental parameters are divided into 5 categories, each category refers to a more detailed explanation.

\section{Tab. 1 Environmental design parameters}

\begin{tabular}{cl}
\hline Category & \multicolumn{1}{c}{ Refers to: } \\
\hline Reduce & $\begin{array}{l}\text { The reduction of raw materials, simplification of the furniture } \\
\text { structure, rethinking of cutting processes, and reuse and } \\
\text { recycling of residues among others. }\end{array}$ \\
\hline Facilitate & $\begin{array}{l}\text { Design of new systems to facilitate the assembly of the } \\
\text { furniture with fewer pieces and fewer tools. }\end{array}$ \\
\hline Extend lifespan & $\begin{array}{l}\text { Offers maintenance packages for the furniture to expand } \\
\text { the lifespan. }\end{array}$ \\
\hline Select & $\begin{array}{l}\text { Use of alternative wood types (including composed) and the } \\
\text { use of certified wood sources. }\end{array}$ \\
\hline Valorize the difference & $\begin{array}{l}\text { Let the customers know the new aspect of the furniture to } \\
\text { highlight the efforts to turn "green". }\end{array}$ \\
\hline
\end{tabular}

Source: Gutiérrez Aguilar et al., 2017, p. 3

The application of the ecodesign parameters resulting in reduction of the use of raw material by $30 \%$, in a reduction in waste by $49 \%$ and in allowing a reduction in energy by $36 \%$ due to simplification of the productive process. Among the strategies applied were reshaping pieces, redesigning, and the substitution of materials (Gutiérrez Aguilar et al. 2017).

Cordero et al. (2010) claim that the benefits of eco-design include reducing environmental impacts, reducing company costs, developing innovative products, potential marketplace advantages, and enhancing a company's societal image.

According to Lofthouse and Bhamra (2007) sustainable design can offer organizations the opportunity to increase sustainability performance while increasing their profitability. By applying the concept of sustainable design, companies can: (1) reduce the environmental impact of their products / processes, (2) optimize the consumption of raw materials and energy use, (3) improve waste management / pollution prevention systems and (4) support the innovation process. 
According to some studies (Govindan et al., 2015; Klinpikul \& Srichandr, 2010; Ratnasingam \& Wagner, 2009), compliance with regulations has been the most important driver of sustainable design implementation in furniture. However, other factors also play an important role in driving sustainable design - potential financial benefits, cost reduction, the perceptions of stakeholders and customers, product positioning relative to competitors and differentiation in the market. Overall, the implementation of sustainable design seems to have a competitive aspect.

Table 2 shows summarizing list of mentioned surveys.

Tab. 2 A review of the authors who researched the implementation of sustainable design or eco-design in the furniture industry.

\begin{tabular}{|l|l|l|}
\hline Year & Author & Researched \\
\hline 2007 & Lofthouse, Bhamra & $\begin{array}{l}\text { The benefits of sustainable design for the } \\
\text { organization. }\end{array}$ \\
\hline 2009 & Ratnasingam, Wagner & $\begin{array}{l}\text { The contributing factors for the adoption of } \\
\text { green manufacturing practices among wooden } \\
\text { furniture manufacturers in Malaysia. }\end{array}$ \\
\hline 2010 & Cordero & $\begin{array}{l}\text { The benefits of eco-design for the environment } \\
\text { and the company. }\end{array}$ \\
\hline 2011 & Klinpikul \& Srichandr & $\begin{array}{l}\text { The driving forces that drive or hinder eco- } \\
\text { design activities. }\end{array}$ \\
\hline 2014 & Valipoor, Ujang & $\begin{array}{l}\text { The main challenges for sustainable design in } \\
\text { furniture industry in Malaysia. }\end{array}$ \\
\hline 2015 & Iritani et al. & $\begin{array}{l}\text { The analysis of the key environmental issues in } \\
\text { the furniture sector. }\end{array}$ \\
\hline 2015 & Govindan et al. & $\begin{array}{l}\text { The using the Life Cycle Assessment model to } \\
\text { analyse sustainable strategies and estimate the } \\
\text { environmental performance in wood-based } \\
\text { furniture. }\end{array}$ \\
\hline 2016 & Linkosalmi et al. & $\begin{array}{l}\text { The drivers of green manufacturing. } \\
\text { The main factors impacting greenhouse gas } \\
\text { emissions from wood-based furniture based in } \\
\text { Finland. }\end{array}$ \\
\hline 2017 & Lewandowska et al. & $\begin{array}{l}\text { The analysis of the design solutions from the } \\
\text { point of view of several criteria (costs, } \\
\text { environmental impact, social aspects) and } \\
\text { several life cycle stages. }\end{array}$ \\
\hline
\end{tabular}

Source: own processing

\subsection{Sustainable design - a connection with the consumer}

The Green Home Furnishings Consumer study (Sustainable Furnishings Council, 2017) was conducted to assess consumer awareness, interest and behaviour in relation to sustainable furniture. The three most important attributes that respondents look for when buying furniture are quality (99\%), style (99\%) and fair price (98\%). On average, respondents expect the 
durability of the furniture will be at least eight years. $57 \%$ of respondents are willing to pay up to $5-10 \%$ more for equipment they consider environmentally friendly, including wooden furniture that is certified of legal and responsibly harvested wood, and for household equipment that is certified as environmentally safe.

According to Nicholls and Stiefel (2007), socio-demographic factors, including age, gender and income, are related to the preferences of different furniture products. This is in line with some findings by Nicholls and Bumgardner (2007), who noted some socio-demographic statistical differences in preferences among furniture consumers. Age and income were both found to be statistically significant, with age having a stronger effect. In contrast, gender was not found to be statistically significant (Kaputa et al. 2018).

In terms of ecological furniture, the socio-demographic elements of consumers (age, residence, income and education) and family size have a significant impact on their willingness to buy this type of furniture (Chitra 2007).

In the U.S., there is a large gap between generations when it comes to sustainable purchase intent. When surveyed, Millennials are twice as likely (75\% vs. 34\%) than Baby Boomers to say they are definitely or probably changing their habits to reduce their impact on the environment. They are also more willing to pay more for products that contain environmentally friendly or sustainable ingredients $(90 \%$ vs. $61 \%)$, organic / natural ingredients $(86 \%$ vs. $59 \%$ ), or products that have social responsibility claims (Nielsen, 2017).

Shrum et.al (1995) have created a psychographic profile of the green consumers. The findings show that the green consumers are cautious shoppers looking for product information, including information on advertising, but also suggest that green consumers are quite sceptical about advertising. As a result, green consumers may be sensitive to green marketing and advertising, but marketers should take care not to discourage them by the use of ambiguous or misleading messages.

Olšiaková et al. (2016) monitored the changes in consumer requirements for wood products in terms of the consumer behaviour in 2004 and 2014. They found that price was no longer the most important factor for Slovak consumers in 2014 because the rate of dissatisfaction of consumers with the price of wood products remarkably decreased by $35 \%$, while the satisfaction with wood products quality increased by $80 \%$. The same findings were presented in the study by Parobek et al. (2015), where Slovak consumers placed a lower importance on price as a criterion in their buying decision.

Kaputa et al. (2018) analysed consumer preferences for wooden furniture in Croatia and Slovakia. Over $78 \%$ of the Croatian respondents considered manufacturing quality and price to be the most important attributes. In Slovakia, the manufacturing quality had the highest percentage of importance (85\%). Strong preferences for the design of the furniture (approximately $74 \%$ of positive answers) were also expressed by the respondents of both countries.

IKEA, in cooperation with the research agency KANTAR HOFFMAN, published a survey on sustainability in Slovakia in 2020. The survey showed that we most often get rid of home furniture only when it is old, destroyed and shabby (63\%), when we need another size (19\%) or when it goes out of fashion (18\%). Half of Slovaks have never bought any used furniture. Almost $1 / 3$ of this group of consumers have never even considered it, others are not worth buying used furniture at the offered price (23\%), buying seems risky $(21 \%)$ or unhygienic $(18 \%)$. It is to change this approach that we should continue to work to minimize waste and move more towards households with sustainable furniture.

According to White et al (2019) most consumers report positive attitudes toward eco-friendly products and services, but they often seem unwilling to pay for them. In one recent survey $65 \%$ said they want to buy purpose-driven brands that advocate sustainability, yet only about 
$26 \%$ actually do so. It is essential to encourage consumers toward sustainable purchasing and behaviour. Authors have identified five actions for companies to consider: use social influence, shape good habits, leverage the domino effect, decide whether to talk to the heart or the brain, and favour experiences over ownership.

The global trend in furniture and housing (according to Interzum-the world's leading trade fair for furniture production and interior design, 2019) focuses on three main topics that will be the focus of attention in the future. The first area aims for conscious, sustainable housing (solutions for smaller living spaces, furniture and model sharing, as well as sustainable production, use and recycling). Another trend is the individualization of living spaces and personalization of furniture (modular furniture concepts, individualized products). The third trend deals with digitization in the context of furniture and accessories (robots, sensors and smart home technologies).

\section{CONCLUSION}

The results presented, regardless of the country of origin, show that there is a positive tendency to adopt sustainable furniture and an increased awareness of the availability of sustainable products. The aim of the paper was to provide an insight into the possibilities of applying sustainability in the furniture industry and to support discussion about the connection between the concept of sustainable development and consumption in the furniture industry. From the case studies that we reviewed, some tools and principles of sustainable design can be highlighted that could support the development of the furniture industry and reduce the impact on the environment.

It is important to involve designers at the beginning of product creation in decisions about appearance, choice of materials, properties and quality features such as repairability, ease of maintenance and durability. The application of environmental design parameters could result in reduction of the use of raw material and energy, in a reduction in waste and in a simplification of the production process. Sustainable design offers furniture companies the opportunity not only to increase their sustainability performance, but also to increase their profitability and improve their brand reputation and value.

Demand for sustainable products is growing - especially among younger consumers. According to surveys, most consumers are willing to pay more for furniture that is certified as environmentally safe. Furniture manufacturers need to be able to respond to customer needs and wishes while also considering environmental and social impacts. A synthesis of the product design literature shows several drivers of sustainable design. Although regulations are the driving force in many cases, the full creative potential of design is linked to market demand. Designers should communicate and collaborate directly with end users. A business model focused on well-designed and attractive products contributes to the overall lifespan of the furniture products with a higher value.

We have identified the area of conscious and sustainable housing as a significant trend in the furniture industry. When looking for a better lifestyle, consumers are looking for options that are healthier for them and their homes. Proven sustainability, flexibility and various types of improvements will become crucial elements for furniture companies that want to achieve longterm success and competitive advantage. 


\section{ACKNOWLEDGEMENT}

The paper was created as part of a grant project VEGA 1/0543/18 "The Importance of Product Design in Consumer Decision-Making and Perspectives to Increase the Impact of Design on Creating Competitive Position of Companies Operating in the Slovak Republic".

\section{REFERENCES}

Albaek, J. K., Shahbazi, S., McAloone, T. C., \& Pigosso, D.C.A. (2020). Circularity evaluation of alternative concepts during early product design and development. Sustainability, 12(22), 1-25. https://doi.org/10.3390/su12229353

Bakker, C. A., den Hollander, M. C, van Hinte, E., \& Zijlstra, Y. (2014). Product that Last. Product Design for Circular Business Models. Delft: TU Delft Library.

Ceschin, F., \& Gaziulusoy, I. (2016). Evolution of design for sustainability: From product design to design for system innovations and transitions. Design Studies, 47, 118-163. https://doi.org/10.1016/j.destud.2016.09.002

Cooper, T. (2000). Product development implications of sustainable consumption. The Design Journal, 3(2), 46-57. https://doi.org/10.2752/146069200789390150

Cooper, T. (2005). Slower consumption: reflections on product life span and the throwaway society. Journal of Industrial Ecology, 9(2), 51-67.

https://doi.org/10.1162/1088198054084671

Cordero, P., Poler, R., \& Sanchis, R. (2010). Identification of the key sustainability issues to develop new decision support tools in the Spanish furniture sector. International Journal of Business, Human and Social Sciences, 4(6), 1368-1380. doi.org/10.5281/zenodo.1080346

Dostatni, E. (2015). Functionality assessment of ecodesign support system. Management and production engineering review, 6(1), 10-15. https://doi.org/0.1515/mper-2015-0002

European Commission. (2018). Sustainable product policy. Retrieved 20 December 2020, from https://ec.europa.eu/jrc/en/research-topic/sustainable-product-policy

Global Consumer Confidence Survey, conducted in collaboration with Nielsen Q2 2017 - The Evolution of the Sustainability Mindset - Nielsen, The Sustainable Consumer - the theme for World Consumer Rights Day 2020 - Consumers International (2020). Retrieved 25 November 2020, from https://www.consumersinternational.org/what-we-do/world-consumer-rightsday/sustainable-consumer-2020/.

Govindan, K., Diabat, A., \& Shankar, M. (2015). Analyzing the drivers of green manufacturing with fuzzy approach. Journal of Cleaner Production, 96, 182-193. https://doi.org/10.1016/j.jclepro.2014.02.054

Gutiérrez Aguilar, C.M., Panameño, R., Perez Velazquez, A., Angel Álvarez, B.E., Kiperstok, A., \& César, S.F. (2017). Cleaner production applied in a small furniture industry in Brazil: Addressing focused changes in design to reduce waste. Sustainability, 9(10), https://doi.org/10.3390/su9101867

Chitra, K. (2007). In search of the green consumers: A perceptual study. Journal of Services Research 7(1), 173-191.

IKEA, KANTAR HOFFMAN. (2020). Je naozaj udržatel'ný život luxus? Prieskumy ukázali ako Slováci šetria planétu aj peniaze. Retrieved 28 December 2020, from https://refresher.sk/90437-Je-naozaj-udrzatelny-zivot-luxus-Prieskumy-ukazali-ako-Slovacisetria-planetu-aj-peniaze 
Iritani, D.R., Silva, D.L., Saavedra, Y.M.B., Grael, P.F.F., \& Ometto, A.R. (2015). Sustainable strategies analysis through Life Cycle Assessment: a case study in a furniture industry. Journal of Cleaner Production, 96, 308-318. https://doi.org/10.1016/j.jclepro.2014.05.029

Kaputa, V., Pirc Barčić, A., Mat'ová, H., \& Motik, D. (2018). Consumer preferences for wooden furniture in Croatia and Slovakia, BioResources, 13(3), 6280-6299.

Klinpikul, N. \& Srichandr, P. (2010). Status of eco-design in Thai furniture industry. Key Engineering Materials, 419-420, 769-772. https://doi.org/10.4028/www.scientific.net/KEM.419-420.769

Ko, Y.-T. (2020). Modelling an innovative green design method for sustainable products. Sustainability, 12(8), 1-23. https://doi.org/10.3390/su12083351

Lewandowska, A., Branowsk, B., Joachimiak-Lechman, K., Kurczewski, P., Selech, J., \& Zablocki, M. (2017). Sustainable Design: A Case of Environmental and Cost Life Cycle Assessment of a Kitchen Designed for Seniors and Disabled People. Sustainability 9(8), 120. https://doi.org/10.3390/su9081329

Linkosalmi, L., Husgafvel, R., Fomkin, A., Junnikkala, H., Witikkala, T., Kairi, M., \& Dahl, O. (2016). Main factors influencing greenhouse gas emissions of woodbased furniture industry in Finland. Journal of Cleaner Production, 113, 596- 605. https://doi.org/10.1016/j.jclepro.2015.11.091

Lofthouse, V., \& Bhamra, T. (2007). Design for Sustainability: A Practical Approach. Hampshire: Gower Publishing Ltd.

Medkova, K., \& Fifield, B. (2016). Circular Design - Design for Circular Economy. In Lahti Cleantech Annual Review, 32-47). Lahti; Lahti University of Applied Sciences. Retrieved 27 December 2020 , from: https://www.theseus.fi/bitstream/handle/10024/121322/LAMK_2016_24.pdf\#page=32.

McCollough, J., Bayramoglu, M. F., \& He, M. (2018). Transitioning into a 'throwaway planet'. International Journal of Consumer Studies, 42(1), 131-140. https://doi.org/10.1111/ijcs.12402

Mont, O., \& Plepys, A. (2008). Sustainable consumption progress: should we be proud or alarmed? Journal of Cleaner Production, 16(4), 531-537. https://doi.org/10.1016/j.jclepro.2007.01.009

Moreno, M., De los Rios, C., Rowe, Z., \& Charnley. (2016). A Conceptual Framework for Circular Design. Sustainability, 8(9), 937. https://doi.org/10.3390/su8090937

Nicholls, D., \& Bumgardner, M. (2007) Evaluating selected demographic factors related to consumer preferences for furniture from commercial and from underutilized species. Forest Products Journal, 57(12), 79-82.

Olkowicz, M., \& Grzegorzewska, E. (2014). Eco-design as a strategic way to competitiveness in global markets for furniture family-owned MSMEs. Journal of Intercultural Management, 6(4), 203-214. https://doi.org/10.2478/joim-2014-0046.

Olšiaková, M., Loučanová, E., \& Paluš, H. (2016). Monitoring changes in consumer requirements for wood products in terms of consumer behaviour. Acta Facultatis Xylologiae Zvolen, 58(1), 137-147. https://doi.org/10.17423/afx.2016.58.1.15

Papanek, V. (1985). Design for the Real World: Human Ecology and Social Change. Chicago: Academy Chicago. 
Parobek, J., Loučanová, E., Kalamárová, M., Šupín, M., \& Štofková, K. R. (2015). Customer window quadrant as a tool for tracking customer satisfaction on the furniture market. Procedia Economics and Finance, 34, 493-499. https://doi.org/10.1016/S2212-5671(15)01659-7

Ratnasingam, J., Wagner, K. (2009). Green manufacturing practices among wooden furniture manufacturers in Malaysia. European Journal of Wood and Wood Products, 67, 485-486. https://doi.org/10.1007/s00107-009-0341-1

Shrum, L.J., Mc Carty, J., \& MCowrey, T. (1995). Buyer characteristics of the green consumers and their implications for advertising strategy. Journal of Advertising, 24, 71-90. https://doi.org/10.1080/00913367.1995.10673477

Spangenberg, J. H., Fuad Luke, A., \& Blincoe, K. (2010). Design for sustainability (DfS): the interface of sustainable production and consumption. Journal of Cleaner Production, 18(15), 1485-1493. https://doi.org/10.1016/j.jclepro.2010.06.002

Sustainable Furnishings Council - 2017 GREEN HOME FURNISHINGS CONSUMER STUDY (2017). $\quad$ Retrieved 25 November 2020, from http://sustainablefurnishings.org/sites/default/files/Resources/SFCconsumerResearchReport2 017_0118.pdf

Trendy z vel'trhu Interzum - Udržatel'nost'. (2019). Retrieved 25 November 2020, from https://www.demos-trade.sk/trendy-z-veltrhu-interzum-udrzatelnost/

Valipoor, S., \& Ujang, B. (2011). Challenges of sustainable design in Malaysian furniture industry. In 2011 International conference on environment and industrial innovation (pp. 6064). IACSIT Press, Singapore. Retrieved 27 December 2020, from https://www.academia.edu/5317631/Challenges_of_Sustainable_Design_in_Malaysian_Furnit ure_Industry.

White, K., Hardisty, D.J., \& Habib, R. (2019). The Elusive Green Consumer. In Harvard Business Review. Retrieved 27 December 2020, from https://hbr.org/2019/07/the-elusivegreen-consumer. 